OPEN ACCESS

Edited by:

Sarah Lebeer,

University of Antwerp, Belgium

Reviewed by:

Giuseppe Spano,

University of Foggia, Italy

Pasquale Russo

University of Foggia, Italy

*Correspondence:

R. Paul Ross

p.ross@ucc.ie

tThese authors have contributed equally to this work

Specialty section:

This article was submitted to

Food Microbiology

a section of the journal

Frontiers in Microbiology

Received: 06 June 2018

Accepted: 20 August 2018 Published: 10 September 2018

Citation:

Hill D, Sugrue I, Tobin C, Hill C, Stanton C and Ross RP (2018) The Lactobacillus casei Group: History and Health Related Applications.

Front. Microbiol. 9:2107.

doi: 10.3389/fmicb.2018.02107

\section{The Lactobacillus casei Group: History and Health Related Applications}

\author{
Daragh Hill1,2,3t, Ivan Sugrue $2,3,4 t$, Conor Tobin ${ }^{2,3,4 t}$, Colin Hill ${ }^{3,4}$, Catherine Stanton ${ }^{2,3}$ and \\ R. Paul Ross ${ }^{3 *}$
}

${ }^{1}$ School of Food and Nutritional Sciences, University College Cork, Cork, Ireland, ${ }^{2}$ Teagasc, Moorepark, Food Research Centre, Fermoy, Ireland, ${ }^{3}$ APC Microbiome Ireland, Cork, Ireland, ${ }^{4}$ School of Microbiology, University College Cork, Cork, Ireland

The Lactobacillus casei group (LCG), composed of the closely related Lactobacillus casei, Lactobacillus paracasei, and Lactobacillus rhamnosus are some of the most widely researched and applied probiotic species of lactobacilli. The three species have been extensively studied, classified and reclassified due to their health promoting properties. Differentiation is often difficult by conventional phenotypic and genotypic methods and therefore new methods are being continually developed to distinguish the three closely related species. The group remain of interest as probiotics, and their use is widespread in industry. Much research has focused in recent years on their application for health promotion in treatment or prevention of a number of diseases and disorders. The LCG have the potential to be used prophylactically or therapeutically in diseases associated with a disturbance to the gut microbiota. The group have been extensively researched with regard to stress responses, which are crucial for their survival and therefore application as probiotics.

Keywords: lactobacillus, casei, paracasei, rhamnosus, health, stress, taxonomy

\section{INTRODUCTION}

There are more than 200 species of Lactobacillus, the largest and most diverse genus within the lactic acid bacteria (LAB) (Sun et al., 2015). Lactobacillus spp. are part of the microbiota of humans and animals (Casey et al., 2004) where they colonize the gastrointestinal tract (GIT) and the urogenital tract (Parolin et al., 2015). They are also found in a variety of food products from fruit and vegetables (Savino et al., 2012) to a range of naturally fermented products (Ao et al., 2012; Owusu-Kwarteng et al., 2015). Lactobacillus spp. have been deployed and studied extensively as fermentation starter cultures (Aryana and Olson, 2017) and as probiotics (Ryan et al., 2015; Pace et al., 2015). Their long history of use in fermented products has led to their recognition as GRAS (generally recognized as safe) by the US Food and Drug Authority (FDA), and earned them a place on the QPS (qualified presumption of safety) list assembled by the European Food Safety Authority (EFSA, 2016).

The Lactobacillus casei group (LCG), comprised mainly of the closely related Lactobacillus casei, Lactobacillus paracasei, and Lactobacillus rhamnosus species, are among some of the most studied species due to their commercial, industrial and applied health potential. Commercially, they are used to ferment dairy products, often producing foods with improved flavor and texture. They have also been found to produce many bioactive metabolites which can confer host benefits when 
consumed (Dietrich et al., 2014). As such, many LCG strains are considered to be probiotics. One member, L. rhamnosus GG (LGG), is perhaps one of the most studied bacterial strains in relation to health applications (Segers and Lebeer, 2014).

This review will discuss the complex issues relating to the taxonomy of the LCG, current research and novel applications of species and strains within the group for health promotion, and will consider stress response mechanisms crucial for probiotic survival.

\section{A BRIEF TAXONOMIC HISTORY}

The LCG is composed of three genotypically and phenotypically related facultatively heterofermentative species, $L$. casei, $L$. paracasei, and L. rhamnosus. The taxonomy of these species has been extensively investigated in the past, as many strains within the group are commonly applied as starter cultures and probiotics. As species of the LCG are of significant commercial value, their relationship to one another has been the focus of much research. It is important to emphasize that distinguishing them is important to ensure correct evaluation of the literature and to avoid confusion between related probiotic strains in food and health-associated products. However, the taxonomic history of the LCG has been both convoluted and challenging.

Lactobacillus casei was first proposed as a novel species in 1971 (Hansen and Lessel, 1971), but this characterisation was first questioned in 1996 (Dicks et al., 1996). It was proposed that the type strain L. casei ssp. casei ATCC 393 and L. rhamnosus ATCC 15820 should be reclassified as the previously described L. zeae (Kuznetsov, 1959), due to high similarity to one another and separation from the rest of the LCG cluster. The name L. paracasei was rejected, and L. casei ATCC 334 was suggested as the new type strain for the species (Dicks et al., 1996). Further research continued to call into question the phylogenetic relationship between the species using more refined methods such as comparative sequence analysis of the recA gene (Felis et al., 2001) and 23S-5S rRNA intergenic spacer regions (Chen et al., 2000). In 2002, it was proposed that the strain designated L. casei ssp. casei ATCC 393 should in fact be reclassified as L. zeae and that $L$. paracasei strains should be reclassified under $L$. casei ATCC 334 (Dellaglio et al., 2002). In 2008, the type strain of L. casei was confirmed to be the original strain ATCC 393, and the strain designated ATCC 334 was rejected as it represented a separate taxon, L. paracasei (Tindall, 2008). The revived name L. zeae was deemed to contravene Rules 51b (1) and (2) of the International Code of Nomenclature of Bacteria and has since been superseded by L. casei (Tindall, 2008). Current research continues to compare and reclassify known species within the group according to developed and novel methods.

\section{DIFFICULTIES IN SPECIATION}

The guidelines for probiotics in food according to the Food and Agriculture Organization of the United Nations and the World Health Organization (FAO/WHO) makes it mandatory that microorganisms which are used intentionally in food or animal feed must be taxonomically defined to genus and species level (FAO/WHO, 2002). As species of the LCG are present in a diverse range of habitats, and are used in the production of many food products in the food industry, molecular genotyping is crucial for determining their evolution and phylogeny. The LCG contains a high number of carbohydrate utilization gene clusters, allowing for survival and adaptation across a number of different environments (Cai et al., 2009). Traditional methods of characterisation for most species include phenotypic analysis such as carbohydrate fermentation profiles (Boyd et al., 2005), however, the gain and loss of plasmids can influence this phenotype and can make identification of strains problematic. Molecular genotyping through comparative analysis of the 16S rRNA gene is another widely used method of species identification (Weisburg et al., 1991). The 16S subunit of the bacterial ribosome is commonly used for species identification and differentiation as it is both ubiquitous and contains regions which are conserved among bacteria. Hypervariable regions flanked by these conserved sequences allow for species identification based on sequence similarity, and has been used as the gold standard approach that avoids potentially confusing phenotypic identification methods (Petti et al., 2005). However, $16 \mathrm{~S}$ gene analysis is not always reliable for LCG species due to high sequence similarities across the three species. Denaturing gradient gel electrophoresis (DGGE), which discriminates based on DNA fragment mobility under increasingly denaturing conditions, has been applied for the identification of LCG species, but has produced confusing results when compared with restriction endonuclease analysis of total chromosomal DNA (Vásquez et al., 2005). A comparison of randomly amplified polymorphic DNA (RAPD) analysis, ribotyping, and pulse field gel electrophoresis (PFGE) have all been applied for the differentiation of LCG species, but often yield contradictory results which lead to differing levels of speciation (Tynkkynen et al., 1999).

\section{CURRENT AND FUTURE TRENDS}

In recent years, other methods have been employed for the classification of LCG strains, see Table 1. A combined technique approach has been suggested to assist where conflicts occur in speciation (Iacumin et al., 2015). Using species-specific PCR and high-resolution melting (HRM) analysis on 201 strains from international culture collections belonging to the $L$. casei group, it was determined that 46 strains were different from their previous classification (Iacumin et al., 2015). A study was also conducted on 40 L. casei strains from plant material, human GITs, human blood, cheeses from different geographical regions, and unknown sources; these were characterized according to standard phenotypic methods (API biochemical testing) and multilocus sequence typing (MLST) using 6 housekeeping genes, together with PFGE (Cai et al., 2007). MLST revealed between 11 and 20 'allelic types' based on the $n r d D$ and mutL genes, and 36 sequence types. The study determined that PFGE was an effective method for discriminating isolates, even where MLST was unsuccessful 
TABLE 1 | Recent publications differentiating species within the L. casei group.

\begin{tabular}{|c|c|c|c|c|}
\hline $\begin{array}{l}\text { Method of species } \\
\text { differentiation/classification }\end{array}$ & \# Strains & Results & Pros and cons to method & Reference \\
\hline $\begin{array}{l}\text { MALDI-TOF MS analysis of } \\
\text { protein biomarker profile with } \\
\text { proteomic analysis using } \\
\text { in-house database }\end{array}$ & 49 & $\begin{array}{l}100 \% \text { discrimination between } \\
\text { L. paracasei subspecies. } \\
\text { Discrepancies found between } \\
\text { probiotic product descriptions and } \\
\text { biomarker identification. }\end{array}$ & $\begin{array}{l}\text { + Rapid, accurate and cheap identification } \\
\text { - Initial high cost of equipment } \\
\text { - Requires database of known species } \\
\text { biomarker profiles }\end{array}$ & Huang and Huang, 2018 \\
\hline Comparative genomics & 183 & $\begin{array}{l}\text { Strains separated into three clades } \\
\text { based on whole GC content, } \\
\text { relatedness of conserved genes, } \\
\text { and clustered based on functional } \\
\text { genomic categories. }\end{array}$ & $\begin{array}{l}\text { + large number of comparison can be } \\
\text { made with publicly available data } \\
\text { - Potential difficulties with acquiring } \\
\text { complete whole genomes of new strains }\end{array}$ & Wuyts et al., 2017 \\
\hline $\begin{array}{l}\text { Multiplex PCR targeting the } \\
\text { mutL gene }\end{array}$ & 76 & $\begin{array}{l}88 \% \text { of strains identified, and } \\
\text { improved characterization of } 10 \\
\text { strains which couldn't be identified } \\
\text { by } 16 \mathrm{~S} \text {. }\end{array}$ & $\begin{array}{l}\text { + Rapid method which can be used with } \\
\text { relative ease (PCR based assay) } \\
\text { + Can be used as a combined approach } \\
\text { - Can provide some ambiguous results }\end{array}$ & Bottari et al., 2017 \\
\hline $\begin{array}{l}\text { Species specific PCR and } \\
\text { high-resolution melting (HRM) } \\
\text { analysis }\end{array}$ & 201 & $\begin{array}{l}96.5 \% \text { of strains identified as part } \\
\text { of the LCG. } 23.7 \% \text { were in } \\
\text { disagreement with species specific } \\
\text { PCR. }\end{array}$ & + Highly sensitive post- PCR technique & lacumin et al., 2015 \\
\hline $\begin{array}{l}\text { Phylogenetic analysis based on } \\
\text { the dnaJ gene }\end{array}$ & 30 & $\begin{array}{l}\text { L. casei, L. paracasei and } \\
\text { L. rhamnosus separated, with } \\
\text { better discrimination than the } 16 \mathrm{~s} \\
\text { rRNA gene. }\end{array}$ & $\begin{array}{l}\text { + Gene similarities of } 81.7-85.5 \% \text { at } \\
\text { interspecies level allow for good separation } \\
\text { - Requires specific kit and minisequencing } \\
\text { technology }\end{array}$ & Huang et al., 2015 \\
\hline $\begin{array}{l}\text { PCR amplification and } \\
\text { comparison of } y y c H \text { gene in } \\
\text { LCG type strains }\end{array}$ & 49 & $\begin{array}{l}\text { Strains were distinctly separated } \\
\text { into clades according to species. }\end{array}$ & $\begin{array}{l}+ \text { Average } \% \text { gene identity of } 78.5 \% \\
\text { among type strains allow for strong } \\
\text { separation }\end{array}$ & Huang et al., 2014 \\
\hline $\begin{array}{l}\text { Whole genome sequencing, } \\
\text { annotation and comparative } \\
\text { genomics }\end{array}$ & 10 & $\begin{array}{l}\text { Differentiation of L. casei ATCC } 393 \\
\text { from L. paracasei strains, and } \\
\text { identification of conserved genomic } \\
\text { islands and truncated genes in } \\
\text { separate species. }\end{array}$ & $\begin{array}{l}\text { + In depth analysis of gene clusters } \\
\text { - Limited number of species compared }\end{array}$ & Toh et al., 2013 \\
\hline $\begin{array}{l}\text { Sequence comparison of the } \\
\text { dnaK gene and RFLP }\end{array}$ & 46 & $\begin{array}{l}\text { Strains were distinctly separated } \\
\text { into clades per species. }\end{array}$ & $\begin{array}{l}\text { + Strong separation of species } \\
\text { + PCR based method } \\
\text { - Poor separation of subspecies }\end{array}$ & Huang and Lee, 2011 \\
\hline
\end{tabular}

(Cai et al., 2007). Another MLST study of 224 L. casei isolates from fermented foods using 10 housekeeping genes found no correlation with geographic location or food source, implying a complex evolutionary history and contradicting previous studies (Bao et al., 2016). Other single target genes used for species discrimination include housekeeping genes such as the chaperone protein gene, dnaJ (Huang et al., 2015), dnaK (Huang and Lee, 2011), yycH (Huang et al., 2014), and mutL (Bottari et al., 2017). Indeed, it was found that the dnaJ gene provided better resolution than the $16 \mathrm{~S}$ rRNA subunit gene for comparisons within and between species, and this has been suggested as an alternative marker (Huang et al., 2015). The gene for the DNA mismatch repair protein $m u t L$ has been chosen as a target for species discrimination using multiplex PCR, and was found to provide a rapid method to distinguish $L$. casei, L. rhamnosus and L. paracasei, though in areas where conflicting results were found, whole genome sequencing (WGS) is suggested (Bottari et al., 2017).

Whole genome sequencing has advantages in terms of the amount of sequence data provided, therefore allowing numerous gene target comparisons, and in silico DNA-DNA hybridisation (Stackebrandt et al., 2002). The ever decreasing cost of WGS is pushing current research in that direction. Numerous studies have used WGS as a method for distinguishing species of the LCG, though the methods are not without difficulty. Toh et al. (2013) produced complete genome sequences of L. paracasei JCM 8130 and L. casei ATCC 393, along with a draft sequence of $L$. paracasei COM0101 and a re-annotated L. rhamnosus ATCC 53103 (otherwise known as L. rhamnosus GG), and they compared them to other available sequences from LCG strains. Through comparative genome analysis, a core of 1,682 genes was found among the LCG and extensive genome wide synteny was observed, particularly for genomic islands containing carbohydrate utilization genes. The presence of truncated forms of the $s p a C B A$ pilus gene cluster previously identified in LGG was found in several L. paracasei strains (Toh et al., 2013). Such genomic insights are invaluable in determining evolutionary relationships within the group and may help differentiate strains where conventional methods fail. Comparative genomic analysis of 213 lactobacilli determined that the LCG clade harbor the most piliated species, which is unsurprising due to their well-known colonization of the GIT (Sun et al., 2015). Until now, such pan- and coregenome approaches have largely been ignored in taxonomy, though more studies are performing comparative genomics in order to determine evolutionary relationships, which in turn 
provide insights into taxonomy (Inglin et al., 2018). Pan-genomic approaches are highlighting inconsistencies in current taxonomy of the group (Wuyts et al., 2017), and comparative genomic studies have revealed high levels of intra-species diversity within the group, even among isolates from the same niche (Stefanovic and McAuliffe, 2018).

Isolates of $L$. casei have been found to have high levels of phenotypic and genotypic diversity, as has been demonstrated through fermentation profiling and MLST analysis (Cai et al., 2007). Comparative genome analysis of carbohydrate utilization clusters of $L$. casei strains found a loss of specific genes which enabled superior adaption for dairy isolates, particularly cheese strains, in the dairy niche, but decreased capacity to inhabit other niches when compared with L. casei 'generalists' as a result (Cai et al., 2009). In addition to gene decay among dairy isolates, comparative genome analysis of dairy, plant, and human strains found horizontal gene transfer from other LAB to be important in adaption of $L$. casei strains to new niches (Broadbent et al., 2012). L. paracasei strains have been found to display similar loss of genes in dairy isolates and high diversity among strains from other sources (Smokvina et al., 2013). It has been suggested that L. rhamnosus species have two distinct genotypes, one adapted to stable nutrient rich environments ie., milk and dairy products, and another which is more suitable to changeable environment such as the GIT (Douillard et al., 2013). A comparison of niche specificity across the LCG may be of interest in the future, in order to help unravel its taxonomic history.

Recently, novel methods have been developed using matrix-assisted laser desorption/ionization time-of-flight mass spectrometry (MALDI-TOF MS) to rapidly identify and classify bacterial isolates according to their protein profiles (Moore and Rosselló-Móra, 2011). This phenotypic proteomic approach has rapidly gained traction, and is being applied in laboratories (Neville et al., 2011), food (Pavlovic et al., 2013), and clinical settings (Samb-Ba et al., 2014). This method has been applied to differentiate species of the LCG after development of an in-house database of phenotypic profiles, and succeeded in identifying strains down to subspecies level (Huang and Huang, 2018). These methods are dependent on phenotypic protein profiles which may shift depending on culture conditions of the bacterium, and difficulties can occur due to initial high cost of equipment. Future approaches will likely depend on combined methods to assist in LCG species and subspecies differentiation, and without an agreed consensus on methods, the taxonomic future of LCG is likely to be as confusing as it's past.

\section{THE L. casei GROUP AND HEALTH RELATED RESEARCH}

The LCG contains numerous strains with proven probiotic activities (Buriti and Saad, 2007). Probiotics are defined as live microorganisms that, when administered in an adequate amount, confer a health benefit on the host (FAO/WHO, 2001; Hill et al., 2014). Bacteria with associated health benefits have been researched since Elie Metchnikoff first suggested that the daily consumption of fermented milk products had a beneficial effect on human health (Ozen and Dinleyici, 2015). This research has been growing steadily over the last 100 years, with great strides having been made in linking health benefits with probiotic consumption. The work on these strains has progressed beyond the use of these bacteria in fermented dairy products, or even fermented foods in general, to a wider array of technological and medicinal purposes. As the mechanisms behind their health promoting capabilities are becoming unraveled, possible applications for these strains are being developed in the food, biotechnology and medical fields (Sanders et al., 2016). This is providing evidence for future novel non-dairy probiotic foods as well as potential for microbial-based therapies for certain disorders and diseases. Some of the more promising applications for the LCG in these fields will be discussed below. The ability of a number of these strains to help maintain a healthy microbiota may provide non-invasive adjunctive therapies for a range of disorders. They could be deployed prophylactically or therapeutically in a number of diseases linked to disturbances in the gut microbiota.

There is great potential in the fields of novel functional foods and pharmabiotics derived from the LCG. However, it should be noted that while many of these strains have been shown to have an effect in in vitro or in vivo mouse models, the underlying mechanisms require further research for any future use as microbial therapeutics.

Health benefits associated with the LCG have been reported for a variety of health conditions, ranging from atopic dermatitis to cancer. The mechanisms by which these bacteria directly or indirectly have a beneficial effect on human health are not yet fully understood and require further study. Potential mechanisms include the production of antimicrobial substances such as bacteriocins, enhancing the epithelial barrier through attachment, competition for pathogenic binding sites, or modulation of the immune system, see Figure 1 (BermudezBrito et al., 2012). The processing and inclusion method of these strains has also been the subject of much interest. For example, the delivery matrix has been shown to influence the effects of L. casei BL23 in the treatment of colitis (Lee et al., 2015). Indeed, this strain only restored the microbiota when consumed in milk.

\section{ALLERGIC DISEASE}

Rates of childhood asthma are rising which has been linked to the hygiene hypothesis (Zhang et al., 2016). Essentially, this proposes that children are exposed to fewer microbes in infancy due to better hygiene, in addition to antibiotic exposure, birth by cesarean section and dietary changes. These factors influence development of the gut microbiota and its immune stimulation in early life. However, through modulation of the gut microbiota, probiotics have shown potential to reduce the risk of developing allergies such as atopic dermatitis. For example, the risk of developing allergy was shown to be reduced at 5 years of age by early life colonization with the LCG in children of both allergic and non-allergic parents (Johansson et al., 2011). The use of probiotics such as LGG have been investigated for their potential protective effect on children with a high risk of developing 


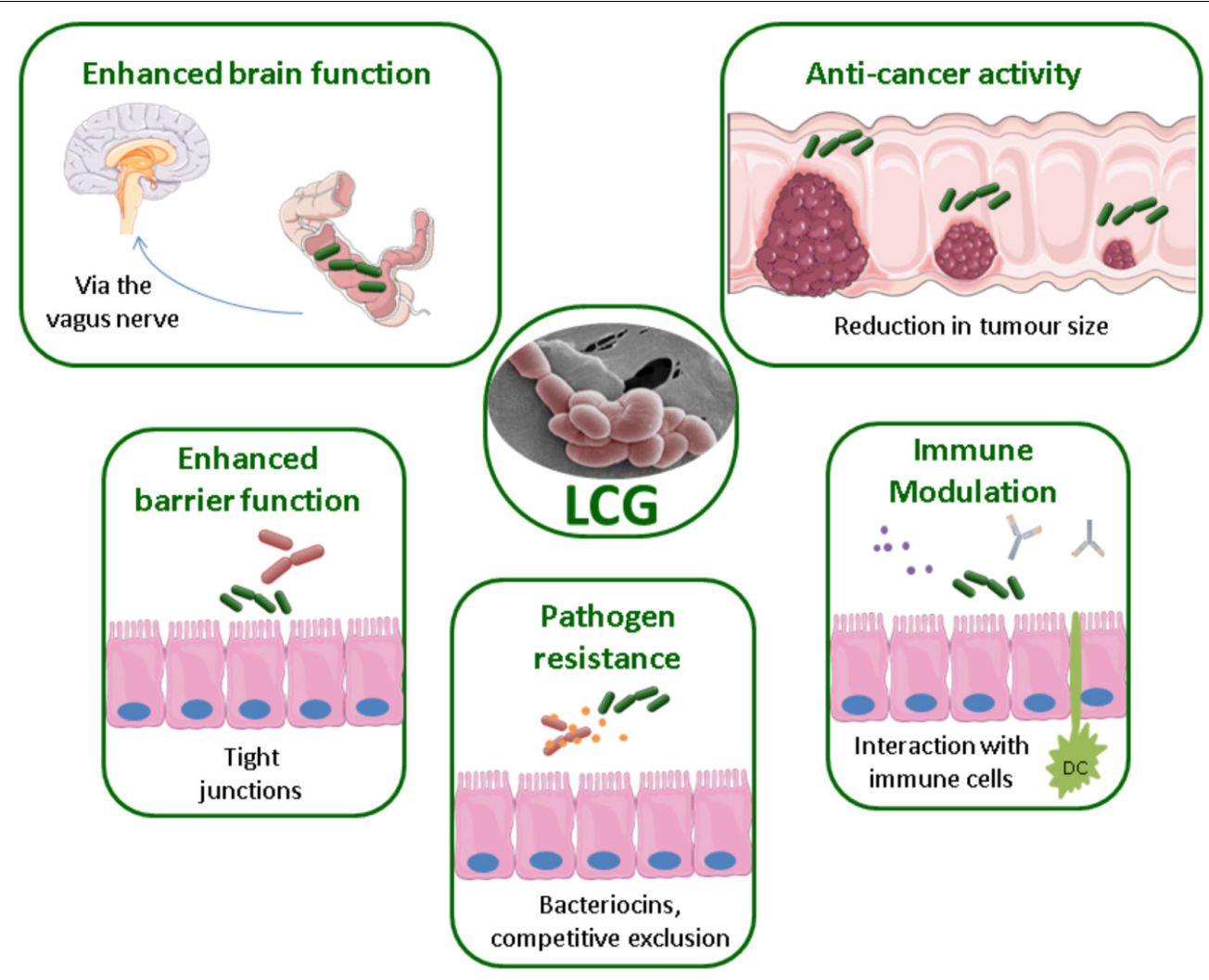

FIGURE 1 | Methods of probiotic action by the LCG, EM of L. paracasei NFBC 338 (McGee et al., 2010).

allergies such as asthma and atopic dermatitis (Kalliomaki et al., 2001). However, this study was recently repeated and found to be ineffective for the prevention of these allergies at 2 years (Cabana et al., 2017). A recent meta-analysis shows that there are confounding results in this area (Huang et al., 2017). While it is important to note this analysis included studies using multiple species and strains, it was concluded that the data overall indicate a benefit to the consumption of a probiotic, although this is dependent on many factors in addition to the specific strain used in the trials.

\section{BRAIN FUNCTION}

A 'psychobiotic' is a bacterium which when administered in adequate amounts can have a positive mental health benefit (Dinan and Cryan, 2017). Members of the LCG have been involved in a number of important studies in this area. In one study focusing on the brain-gut-axis the strain L. rhamnosus JB1 highlighted both the ability of bacteria to positively affect brain function and also the importance of the vagus nerve in the bidirectional communication between gut microbes and the brain. Administration of JB1 directly affected the expression of GABA receptors in the brain which resulted in decreased anxiety and depressive behaviors in mice (Bravo et al., 2011). This study included healthy animals in separate laboratories with the same outcome.
In a recent study, a tablet preparation of LGG and Bifidobacterium lactis $\mathrm{Bb} 12$ as adjunctive therapy on hospitalized patients suffering from mania was effective in lowering rehospitalisation rates (Dickerson et al., 2018). While it is important to note this study had a number of limitations; the direct effect of the probiotic on the microbiome and inflammation of the CNS were not measured, as well as medication taken by the recruits was patient-specific. It does highlight the potential for microbial therapy in mental disorders which warrants further investment and study.

The ingestion of a combination of L. rhamnosus R0011 and L. helveticus R0052 also highlights the potential for bacteria to influence behavior in a mouse model. The study showed that modulation of the gut microbiota can positively influence certain animal behaviors, in this case stress-induced impaired memory (Gareau et al., 2011). The normalization of the gut microbiota through ingestion of this probiotic combination helped to prevent behavior abnormalities caused by infection with Citrobacter rodentium.

\section{OBESITY}

Obesity is a complex syndrome with a variety of contributing factors which influence onset. These include diet, physical activity and genetic factors, but also can be influenced by the composition of the gut microbiota. Manipulation of the microbiota through 
the administration of probiotics is an area that could provide interventions for the prevention and treatment of obesity. In a recent study, the probiotic L. rhamnosus CGMCC1.3724 was administered to obese men and women for 24 weeks. Males showed no significant difference in weight loss, but the female participants in the probiotic group had significant weight loss. This was found to be associated with reductions in blood leptin concentrations (Sanchez et al., 2014). Obesity is also associated with changes in the gut microbiota and immune parameters. A fermented milk containing L. casei CRL 431 fed to mice was able to positively affect the microbiota as well as some biomarkers associated with obesity (Nunez et al., 2014).

In a murine model of obesity $L$. casei Shirota was evaluated for its ability to improve weight management in comparison to Orlistat, a drug used to treat obesity (Karimi et al., 2015). The results of this study showed promise in the use of probiotic strains as an alternative method for weight management. The impact of exposure to probiotics on weight gain before birth has also been investigated. L. rhamnosus administered to pregnant women has been found to modify weight gain in children during the first 6 months of life (Luoto et al., 2010).

\section{CANCER}

Cancer is a global concern with large efforts being devoted to methods to prevent and/or cure the disease. Cancer is the abnormal growth of cells beyond their usual boundaries that can invade adjoining parts of the body and/or spread to other organs (WHO, 2015). Probiotics have been investigated for their potential as an adjunctive therapy and as a microbial therapy for cancer (Huang et al., 2016; So et al., 2017).

The previously mentioned L. casei species type strain ATCC 393 was investigated in an experimental model of colon cancer using both murine and human colon carcinoma cell lines (Tiptiri-Kourpeti et al., 2016). The in vivo model showed an approximately $80 \%$ reduction in tumor volume in mice fed live $L$. casei for 13 days. The bacteria attached to the cancer cells and reduced cancer cell viability and induced apoptotic cell death. While the mechanisms are not fully understood, this provides promising evidence for the use of $L$. casei in the treatment of cancer. L. casei strains have also been investigated for prophylactic treatment in late stage colorectal cancer (CRC). The main cause of death from CRC is the tumor metastasising to other organs. Cell free supernatant from $L$. casei and L. rhamnosus was found to lower the ability of a metastatic tumor cell line to invade in vitro (Escamilla et al., 2012).

Numerous studies have investigated strategies for how probiotic strains may be used to aid tumor reduction. L. casei Shirota has been studied in combination with dietary fiber for its ability to reduce the reoccurrence of tumors in colorectal cancer, with early studies showing promising results (Ishikawa et al., 2005). LGG has also been investigated as a synbiotic with oligofructose and Bifidobacterium lactis Bb12 (Rafter et al., 2007). This promising study showed that the synbiotic was capable of lowering the uncontrolled growth of intestinal cells. This is thought to be due to presence of the synbiotic enhancing the mucosal structure, reducing exposure of epithelial cells to cytotoxic and genotoxic agents, and a decrease in colonic cell growth.

Treatment methods for cancer patients can put a large burden on the immune system and can cause side effects such as diarrhea which, in an immunocompromised individual, can prove fatal. Probiotics have been shown to reduce the likelihood of radiationinduced diarrhea during cancer treatment (Liu et al., 2017). LGG has also been studied as an adjunctive therapy for cancer treatments to reduce the incidence and severity of diarrhea (Banna et al., 2017). It was shown that treatment supplemented with LGG capsules resulted in less grade 3/4 diarrhea, with less abdominal discomfort reported (Osterlund et al., 2007).

\section{DIARRHEA}

According to the WHO, diarrhea is the second highest cause of death in children under 5 years old, and remains a major problem associated with antibiotics. Antibiotic-associated Clostridium difficile infection is the leading cause of diarrhea in highincome countries at all ages. LCG strains have been associated with improving the symptoms and/or duration of diarrhea in numerous studies, but specifically LGG is a promising strain in this regard. The ability of many $L$. casei strains to prevent antibiotic associated diarrhea is associated with its ability to maintain the diversity of the gut microbiome of individuals during antibiotic treatments. This could be due to direct attachment of the strain to epithelial cells. LGG attaches to mucosal cells through the SpaCBA pilus. The SpaC adhesin is present along the entire length of the pilus in large quantities (Reunanen et al., 2012). This adhesin allows both long and close adhesion of the bacterium and aids in the long term colonization of the strain. Vancomycin resistant enterococci, such as Enterococcus faecium also bind to and colonize the gut based on a pilus with high sequence similarity to the LGG SpaCBA pilus. LGG could be used prophylactically or as direct competition in the treatment of enterococcal infections (Tytgat et al., 2016).

\section{MICROBIAL THERAPY THROUGH BACTERIAL COMPONENTS}

The future of probiotics lies not only in the administration of live bacteria but also in the possibility of utilizing bacterial components to modulate the immune system. The ability of L. casei strains to survive passage through the digestive system and potentially colonize the gut allows some strains to have direct effects on human health. However, bacterial components are also being investigated for their health associated capabilities. In one study, a heat-killed strain of $L$. casei was administered in a mouse model of colitis. Both the heat-killed and live strains were shown to have therapeutic effects on a model of inflammatory bowel disease (IBD) (Thakur et al., 2016). The advantage of such a scenario is promising as it eliminates the need for the strain to survive passage through the gut and could potentially provide a more consistent effect as colonization is not required. 
Exopolysaccharides (EPS) are produced by numerous bacteria, sometimes in response to stress. EPS have also been investigated for their health-promoting benefits (Ryan et al., 2015; Caggianiello et al., 2016), such as immunoregulatory effects (Laino et al., 2016). The LCG have long been used in fermentations whether as adjunct or starter cultures. Traditionally these would have been included for their desirable technological properties such as EPS production. Many of these technologically desirable traits have since been investigated for their probiotic potential. For example, EPS produced by L. rhamnosus has been shown to have immunosuppressive capabilities (Bleau et al., 2010). The probiotic strain L. paracasei DG has a range of health promoting properties attributed to it, including its use as an adjunctive therapy in Helicobacter pylori treatment and modulation of the gut microbiota. Recent suggestions that bacterial components may be the mechanism by which probiotics exert their effects sparked a study on the EPS produced by this strain. This study demonstrated that the EPS which is secreted by and covers L. paracasei DG may have a role in its health associated properties (Balzaretti et al., 2017).

Interest in utilizing probiotics for the treatment or prevention of disease is growing, and the studies discussed here highlight some of the potential directions for the future of health related research in the LCG. The LCG exert many of their health benefits when ingested live and are capable of colonizing the gut. To survive transit they must have the propensity to respond to a wide array of stresses. The underlying mechanisms involved in this are becoming clearer.

\section{THE L. casei GROUP AND STRESS RESPONSE}

As probiotics the LCG must endure many stresses during processing and remain viable on transit to their site of action, the GIT. These stresses include but are not limited to bile salts, oxidative stress, cold stress, osmotic stress, acid stress and long term storage. Resistance to these stresses in LCG is strain dependent, with some having a high resistance to multiple stresses while others confer little to no resistance (Reale et al., 2015). The LCG employ many different tactics in order to survive these stresses, including alterations to cell membrane, metabolic pathways, and upregulation of chaperone proteins (Maria and Marco, 2004).

\section{ACID SHOCK}

Due to the facultative heterofermentative nature of LCG, hexose sugars are almost exclusively fermented to lactic acid. The LCG have an innate tolerance to acid stress for this reason. Probiotic bacteria must also endure an acidic environment during gastrointestinal transit. Tolerance to acid stress is particularly relevant in industry for probiotic bacteria. In acidic environments, acids can passively diffuse into cells where they can rapidly dissociate into protons. This lowers the intracellular
$\mathrm{pH}(\mathrm{pHi})$ and affects the transmembrane $\mathrm{pH}$ gradient and the proton motive force (van de Guchte et al., 2002; Corcoran et al., 2008; Mills et al., 2011). Low pHi also causes damages to proteins and DNA. The methods used to counteract acid stress in $L$. casei include the arginine deiminase pathway, F0F1 proton pump, cell membrane alterations and repair of damaged DNA and proteins. Amino acid utilization also plays a physiological role in pHi control in LAB (Fernández and Zúñiga, 2006).

The LCG can exploit amino acids such as arginine, histidine, and aspartate during acidic conditions (Broadbent et al., 2010; Wu et al., 2012a; Wu et al., 2013). This is generally achieved by deamination of the amino acid and the expulsion of the alkaline product from the cell (Corcoran et al., 2008; Papadimitriou et al., 2016). The arginine deiminase pathway is a catabolic system found in $L$. casei that uses arginine to produce ATP, ornithine $\mathrm{CO}_{2}$ and $\mathrm{NH}_{3}$ (Marquis et al., 1987). The system is comprised of three enzymes; arginine deiminase (ADI), catabolic ornithine transcarbamoylase and carbamate kinase, and a singular membrane transport protein (Papadimitriou et al., 2016). The $\mathrm{NH}_{3}$ reacts with protons to help alkalize the extracellular environment. Acid resistant L. casei can overexpress proteins involved with the ADI pathway in acidic conditions ( $\mathrm{Wu}$ et al., 2012a). The F0F1-ATPase is ubiquitous among bacteria (van de Guchte et al., 2002). This multicomponent enzyme is bifunctional; it can produce ATP using protons or alternately pump protons out of the cell by hydrolysing ATP (van de Guchte et al., 2002). In acidic conditions, acid tolerant L. casei show higher levels of ATPase activity than that of acid sensitive cells (Wu et al., 2012a). Bender and Marquis showed that L. casei had a higher ATPase activity that that of the non-acid tolerant Actinomyces viscous in acidic conditions (Bender and Marquis, 1987).

Bacteria also adapt to environmental changes (stresses) by modifying their membrane composition (Zhang and Rock, 2008). The acid tolerant $L$. casei Zhang can increase expression of the proteins MurA and MurG, key enzymes in peptidoglycan synthesis (Wu et al., 2012a). It has been shown that bacteria alter the fatty acid composition of their cytoplasmic membrane in response to acidic conditions but different results have also been reported. Fozo et al. (2004) and Wu et al. (2012b) reported that there is an increase in the unsaturated fat proportions while Broadbent et al. (2010) have reported the opposite in that the ratio of saturated to unsaturated fatty acids increases. L. johnsonii has been shown to become more sensitive to acid stress when supplemented with unsaturated fatty (Muller et al., 2011). These contradicting results could be due to the use of different strains or different experimental conditions. In response to DNA damage, there is an overproduction of DNA repair proteins involved in base excision repair, nucleotide excision repair, mismatch repair, and homologous recombination (Wu et al., 2012a). Proteins involved in the general stress response (DnaK, DnaJ and Hspl) and chaperone proteins (GroEL, GrpE) are also overexpressed (Wu et al., 2011, 2012a, 2014). These proteins are involved in the prevention of incorrect protein folding and repair of damaged proteins at the expense of ATP (Schröder et al., 1993). Many of the reactions of the cell to acid 
stress are energy dependent and therefore require ATP. Wu et al. (2012a) found that while levels of glucose-phosphotransferase system (PTS) activity dropped significantly in acid stressed cells, they were still higher than in sensitive cells. This in turn means more glucose entering glycolysis and more energy (ATP) for the cell to react to acid stress. Nezhad et al. (2012) also showed that there were increased levels of proteins involved with the glycolytic pathway expressed on the cell surface of $L$. casei under acidic conditions.

\section{COLD SHOCK}

Post fermentation, probiotic LCG are going to encounter cold stress in the form of refrigeration. Survival of cold storage is necessary for refrigerated probiotic bacteria to reach their final destination in the human GIT. Cold is a physical stress that affects physico-chemical properties inside cells. It does this by influencing membrane fluidity, diffusion rates and interactions of macromolecules such as proteins, DNA and RNA. Cold shock proteins (CSPs) are produced by bacteria in response to growth at temperatures below optimum conditions. CspA and CspB in $L$. casei have similar sequences to that of the C-terminal of EIIA proteins of the glucose-PTS system (Monedero et al., 2006). It has been suggested that $\mathrm{Hpr}$ phosphorylates these cold shock proteins to activate them in response to cold shock (Beaufils et al., 2007). L. casei mutants unable to form $\mathrm{Hpr}$ ser-45 were much more sensitive to freeze/thaw when grown on glucose as compared to growth on other sugars (Beaufils et al., 2007). This suggests that CSPs have a major role in metabolism at low temperatures. More cold-induced proteins (CIPs) are expressed in cold shock to maintain fluidity of the cell membrane by increasing the ratio of shorter and/or unsaturated fatty acids and to maintain DNA structure by reducing negative supercoiling.

\section{BILE STRESS}

Bile acids (sometimes referred to as salts) are secreted into the intestine of mammals to aid digestion. They also offer another hurdle for bacteria as they have antimicrobial activity. Bile is known to affect the structure of membranes, DNA, RNA and protein folding (Corcoran et al., 2008). Hamon et al. (2012) employed a proteomic method to evaluate bile tolerance in L. case $i$ and suggested the membrane modification protein $\mathrm{RmlC}$, cell wall synthesis protein NagA and NagB, molecular chaperone protein ClpP and proteins involved in central metabolism were key to bile tolerance. Bile salt hydrolase (BSH) is a protein expressed by bacteria commonly found in the intestinal tract that can deconjugate bile salts and also have the added positive effect of lowering serum cholesterol levels and reducing the risk of obesity and arthrosclerosis in the host (Wang et al., 2011). BSH activity has been found in $L$. casei but is not always present (Gilliland and Speck, 1977; Zhang et al., 2009; Wang et al., 2011). There is conflicting evidence whether or not BSH increases tolerance to bile salts with many studies finding a correlation
(Moser and Savage, 2001; Wang et al., 2011) while many others have failed to find correlation between BSH activity and bile tolerance (Begley et al., 2005; Bustos et al., 2012).

\section{OXIDATIVE STRESS}

Oxidative stress refers to the production of Reactive Oxygen Species (ROS) and accumulation in the cell. ROS include superoxide $\left(\mathrm{O}_{2}-\right)$, hydrogen peroxide $\left(\mathrm{H}_{2} \mathrm{O}_{2}\right)$, and hydroxyl radical $(\mathrm{OH})$. ROS can lead to impairment of proteins, lipids, and nucleotides, contributing to the arrest of cell growth and cell death (Imlay, 2003). Some LAB, including L. casei, can utilize oxygen in aerobic conditions for energy production using a pathway which includes pyruvate oxidase, NADH oxidase, NADH peroxidase and acetone kinase, which results in the formation of ROS (Maria and Marco, 2004; Ianniello et al., 2016). Catalase is an enzyme capable of degrading $\mathrm{H}_{2} \mathrm{O}_{2}$ and therefore is a key component in oxidative stress. Indeed, the presence of oxygen has been shown to increase its activity in L. casei (Ianniello et al., 2016). The high Mn content of L. casei can act as an efficient scavenger of $\mathrm{O}_{2}$, thereby compensating for the lack of a superoxide dismutase, while there are currently no known enzymes to degrade hydroxyl radicals (van de Guchte et al., 2002).

\section{OSMOTIC STRESS}

High osmolality is often experienced by the LCG in fermented foods. Food spoilage bacteria and pathogens are often more sensitive to high osmotic conditions compared to $\mathrm{LAB}$, therefore $\mathrm{NaCl}$ is often added to aid indigenous or starter LAB during the fermentation process (Papadimitriou et al., 2016). Salt stress leads to cell wall conformational changes in L. casei, which increases its ability to form biofilms and bind cations (Palomino et al., 2013). High salt conditions cause $L$. casei to become more susceptible to antimicrobial peptides which target cell wall synthesis (Piuri et al., 2005; Palomino et al., 2013).

\section{STORAGE}

Before use as a probiotic, bacteria may need to be stored for long periods of time. The two main methods for preparing them for long term storage are freeze-drying and spray-drying. During freeze drying, cells are subjected to a physical stress caused by crystals forming, dehydration and osmotic stress (Broeckx et al., 2016). Jofré et al. (2015) found members of the LCG survive storage better at refrigeration temperature and skimmed milk alone or supplemented with trehalose or lactose to be a suitable cryoprotectant during freeze-drying. Encapsulation of L. casei cells during freeze drying can also offer protection to cells during storage post freeze drying (Xu et al., 2016).

During spray dryin, bacteria are exposed to many different types of stress which affect the viability of the cells during storage including heat, dehydration, shear, osmotic and oxidative stress (Broeckx et al., 2016). Microencapsulation of the cells in 
a protective agent is one of the main methods of increasing viability during spray drying. L. casei LK-1 microencapsulated in skimmed milk showed better survivability during storage and gastric digestion than cells microencapsulated in trehalose and maltodextrin (Liao et al., 2017). Storage temperature is also a key factor in the viability of cells following this process. An increase of storage temperature from $-20^{\circ} \mathrm{C}$ to $4^{\circ} \mathrm{C}$ or from $4^{\circ} \mathrm{C}$ to $25^{\circ} \mathrm{C}$ causes a three fold acceleration of the inactivation rate of $L$. casei LK (Liao et al., 2017). Higher inactivation rates for L. rhamnosus GG were also reported at room temp following spray drying compared to chilled storage temperatures (Soukoulis et al., 2016).

\section{CONCLUSION}

The LCG contains the species L. rhamnosus, L. casei, and $L$. paracasei; these are well-researched due to their applicability in the food, biopharmaceutical and medical industries. Despite this, the group has a long complicated taxonomic history in distinguishing and discriminating the species from each another. The taxonomic debate surrounding the LCG is likely to continue to prove interesting and challenging as sequencing and novel identification methods are developed.

Stress resistance is associated with the LCG through physical and metabolic alterations; although these resistant phenotypes are strain specific. The LCG must be capable to survive a number of stress conditions if they are to be used in industry, including

\section{REFERENCES}

Ao, X., Zhang, X., Zhang, X., Shi, L., Zhao, K., Yu, J., et al. (2012). Identification of lactic acid bacteria in traditional fermented yak milk and evaluation of their application in fermented milk products. J. Dairy Sci. 95, 1073-1084. doi: 10.3168/jds.2011-4224

Aryana, K. J., and Olson, D. W. (2017). A 100-year review: yogurt and other cultured dairy products. J. Dairy Sci. 100, 9987-10013. doi: 10.3168/jds.201712981

Balzaretti, S., Taverniti, V., Guglielmetti, S., Fiore, W., Minuzzo, M., Ngo, H. N., et al. (2017). A novel rhamnose-rich hetero-exopolysaccharide isolated from Lactobacillus paracasei Dg activates Thp-1 human monocytic cells. Appl. Environ. Microbiol. 83:e02702-16. doi: 10.1128/AEM.02702-16

Banna, G. L., Torino, F., Marletta, F., Santagati, M., Salemi, R., Cannarozzo, E., et al. (2017). Lactobacillus rhamnosus Gg: an overview to explore the rationale of its use in cancer. Front. Pharmacol. 8:603. doi: 10.3389/fphar.2017.00603

Bao, Q., Song, Y., Xu, H., Yu, J., Zhang, W., Menghe, B., et al. (2016). Multilocus sequence typing of Lactobacillus casei isolates from naturally fermented foods in China and Mongolia. J. Dairy Sci. 99, 5202-5213. doi: 10.3168/jds.201610857

Beaufils, S., Sauvageot, N., Maze, A., Laplace, J. M., Auffray, Y., Deutscher, J., et al. (2007). The cold shock response of Lactobacillus casei: relation between Hpr phosphorylation and resistance to freeze/thaw cycles. J. Mol. Microbiol. Biotechnol. 13, 65-75. doi: 10.1159/000103598

Begley, M., Gahan, C. G. M., and Hill, C. (2005). The interaction between bacteria and bile. FEMS Microbiol. Rev. 29, 625-651. doi: 10.1016/j.femsre.2004.09.003

Bender, G. R., and Marquis, R. E. (1987). Membrane atpases and acid tolerance of actinomyces viscosus and Lactobacillus casei. Appl. Environ. Microbiol. 53, 2124-2128.

Bermudez-Brito, M., Plaza-Diaz, J., Munoz-Quezada, S., Gomez-Llorente, C., and Gil, A. (2012). Probiotic mechanisms of action. Ann. Nutr. Metab. 61, 160-174. doi: 10.1159/000342079

Bleau, C., Monges, A., Rashidan, K., Laverdure, J. P., Lacroix, M., Van Calsteren, M. R., et al. (2010). Intermediate chains of exopolysaccharides from oxidative stress, osmotic stress, cold stress, acid stress and long term storage. In addition to their need to tolerate these conditions in food processing, live strains must be able to survive passage through the GIT if intended for health-promoting purposes.

The health-promoting capabilities of the LCG have been documented in several studies suggesting real potential for their use in the treatment, or prevention, of a variety of diseases. Moving forward, it is essential that scientists decipher the underlying mechanisms of action involved in order to be able to apply these strains or their bacterial components as novel treatments or prophylactic interventions.

\section{AUTHOR CONTRIBUTIONS}

$\mathrm{DH}$, IS, and CT contributed equally to the writing of the manuscript. $\mathrm{CH}, \mathrm{CS}$, and $\mathrm{RR}$ contributed to manuscript revision, read, and approved the submission.

\section{FUNDING}

DH, IS, and CT are in receipt of Teagasc Walsh Fellowships. The financial support of the following is gratefully acknowledged: JPI Food Processing for Health funded 'Longlife' and Science Foundation Ireland (SFI) under Grant Number SFI/12/RC/2273 in APC Microbiome Ireland.

Lactobacillus rhamnosus $\mathrm{Rw}-9595 \mathrm{M}$ increase Il-10 production by macrophages. J. Appl. Microbiol. 108, 666-675. doi: 10.1111/j.1365-2672.2009.04450.x

Bottari, B., Felis, G. E., Salvetti, E., Castioni, A., Campedelli, I., Torriani, S., et al. (2017). Effective identification of Lactobacillus casei group species: genomebased selection of the gene mutL as the target of a novel multiplex PCR assay. Microbiology 163, 950-960. doi: 10.1099/mic.0.000497

Boyd, M. A., Antonio, M. A., and Hillier, S. L. (2005). Comparison of API 50 CH strips to whole-chromosomal DNA probes for identification of Lactobacillus species. J. Clin. Microbiol. 43, 5309-5311. doi: 10.1128/JCM.43.10.5309-5311. 2005

Bravo, J. A., Forsythe, P., Chew, M. V., Escaravage, E., Savignac, H. M., Dinan, T. G., et al. (2011). Ingestion of Lactobacillus strain regulates emotional behavior and central Gaba receptor expression in a mouse via the vagus nerve. Proc. Natl. Acad. Sci. U.S.A. 108, 16050-16055. doi: 10.1073/pnas.1102999108

Broadbent, J. R., Larsen, R. L., Deibel, V., and Steele, J. L. (2010). Physiological and transcriptional response of Lactobacillus casei ATCC 334 to acid stress. J. Bacteriol. 192, 2445-2458. doi: 10.1128/JB.01618-09

Broadbent, J. R., Neeno-Eckwall, E. C., Stahl, B., Tandee, K., Cai, H., Morovic, W., et al. (2012). Analysis of the Lactobacillus casei supragenome and its influence in species evolution and lifestyle adaptation. BMC Genomics 13:533. doi: 10.1186/ 1471-2164-13-533

Broeckx, G., Vandenheuvel, D., Claes, I. J. J., Lebeer, S., and Kiekens, F. (2016). Drying techniques of probiotic bacteria as an important step towards the development of novel pharmabiotics. Int. J. Pharm. 505, 303-318. doi: 10.1016/ j.ijpharm.2016.04.002

Buriti, F. C., and Saad, S. M. (2007). Bacteria of Lactobacillus casei group: characterization, viability as probiotic in food products and their importance for human health. Arch. Latinoam. Nutr. 57, 373-380.

Bustos, A. Y., Saavedra, L., De Valdez, G. F., Raya, R. R., and Taranto, M. P. (2012). Relationship between bile salt hydrolase activity, changes in the internal $\mathrm{pH}$ and tolerance to bile acids in lactic acid bacteria. Biotechnol. Lett. 34, 1511-1518. doi: 10.1007/s10529-012-0932-5

Cabana, M. D., Mckean, M., Caughey, A. B., Fong, L., Lynch, S., Wong, A., et al. (2017). Early probiotic supplementation for eczema and asthma prevention: a 
randomized controlled trial. Pediatrics 140:e20163000. doi: 10.1542/peds.20163000

Caggianiello, G., Kleerebezem, M., and Spano, G. (2016). Exopolysaccharides produced by lactic acid bacteria: from health-promoting benefits to stress tolerance mechanisms. Appl. Microbiol. Biotechnol. 100, 3877-3886. doi: 10. 1007/s00253-016-7471-2

Cai, H., Rodriguez, B. T., Zhang, W., Broadbent, J. R., and Steele, J. L. (2007). Genotypic and phenotypic characterization of Lactobacillus casei strains isolated from different ecological niches suggests frequent recombination and niche specificity. Microbiology 153, 2655-2665. doi: 10.1099/mic.0.2007/ 006452-0

Cai, H., Thompson, R., Budinich, M. F., Broadbent, J. R., and Steele, J. L. (2009). Genome sequence and comparative genome analysis of Lactobacillus casei: insights into their niche-associated evolution. Genome Biol. Evol. 1, 239-257. doi: 10.1093/gbe/evp019

Casey, P. G., Casey, G. D., Gardiner, G. E., Tangney, M., Stanton, C., Ross, R. P., et al. (2004). Isolation and characterization of anti-Salmonella lactic acid bacteria from the porcine gastrointestinal tract. Lett. Appl. Microbiol. 39, 431-438. doi: 10.1111/j.1472-765X.2004.01603.x

Chen, H., Lim, C. K., Lee, Y. K., and Chan, Y. N. (2000). Comparative analysis of the genes encoding 23S-5S rRNA intergenic spacer regions of Lactobacillus casei-related strains. Int. J. Syst. Evol. Microbiol. 50(Pt 2), 471-478. doi: 10.1099/ 00207713-50-2-471

Corcoran, B. M., Stanton, C., Fitzgerald, G. \& Ross, R. P. (2008). Life under stress: the probiotic stress response and how it may be manipulated. Curr. Pharm. Des. 14, 1382-1399. doi: 10.2174/138161208784480225

Córdoba Park Hotel Argentina (2001). Health and Nutritional Properties of Probiotics in Food Including Powder Milk with Live Lactic Acid Bacteria - Joint FAO/WHO Expert Consultation. Córdoba: American Córdoba Park Hotel.

Dellaglio, F., Felis, G. E., and Torriani, S. (2002). The status of the species Lactobacillus casei (Orla-Jensen 1916) Hansen and Lessel, 1971 and Lactobacillus paracasei collins et al. 1989. Request for an opinion. Int. J. Syst. Evol. Microbiol. 52, 285-287. doi: 10.1099/00207713-52-1-285

Dickerson, F., Adamos, M., Katsafanas, E., Khushalani, S., Origoni, A., Savage, C., et al. (2018). Adjunctive probiotic microorganisms to prevent rehospitalization in patients with acute mania: a randomized controlled trial. Bipolar Disord. doi: 10.1111/bdi.12652 [Epub ahead of print].

Dicks, L., Du Plessis, E., Dellaglio, F., and Lauer, E. (1996). Reclassification of Lactobacillus casei subsp. casei ATCC 393 and Lactobacillus rhamnosus ATCC 15820 as Lactobacillus zeae nom. rev., designation of ATCC 334 as the neotype of L. casei subsp. casei, and rejection of the name Lactobacillus paracasei. Int. J. Syst. Evol. Microbiol. 46, 337-340. doi: 10.1099/00207713-46$1-337$

Dietrich, C. G., Kottmann, T., and Alavi, M. (2014). Commercially available probiotic drinks containing Lactobacillus casei Dn-114001 reduce antibioticassociated diarrhea. World J. Gastroenterol. 20, 15837-15844. doi: 10.3748/wjg. v20.i42.15837

Dinan, T. G., and Cryan, J. F. (2017). The microbiome-gut-brain axis in health and disease. Gastroenterol. Clin. North Am. 46, 77-89. doi: 10.1016/j.gtc.2016.09.007

Douillard, F. P., Ribbera, A., Kant, R., Pietilä, T. E., Järvinen, H. M., Messing, M., et al. (2013). Comparative genomic and functional analysis of 100 Lactobacillus rhamnosus strains and their comparison with strain Gg. PLoS Genetics 9:e1003683. doi: 10.1371/journal.pgen.1003683

EFSA (2016). Update of the list of Qps-recommended biological agents intentionally added to food or feed as notified to EFSA 4: suitability of taxonomic units notified to EFSA until March 2016. EFSA J. 14:e04522.

Escamilla, J., Lane, M. A., and Maitin, V. (2012). Cell-free supernatants from probiotic Lactobacillus casei and Lactobacillus rhamnosus Gg decrease colon cancer cell invasion in vitro. Nutr. Cancer 64, 871-878. doi: 10.1080/01635581. 2012.700758

FAO/WHO (2001). Health and Nutritional Properties of Probiotics in Food Including Powder Milk with Live Lactic Acid Bacteria - Joint FAO/WHO Expert Consultation. Córdoba: American Córdoba Park Hotel.

FAO/WHO (2002). Joint FAO/WHO Working Group Guidelines for the Evaluation of Probiotics in Food. London: World Health Organization.

Felis, G. E., Dellaglio, F., Mizzi, L., and Torriani, S. (2001). Comparative sequence analysis of a recA gene fragment brings new evidence for a change in the taxonomy of the Lactobacillus casei group. Int. J. Syst. Evol. Microbiol. 51, 2113-2117. doi: 10.1099/00207713-51-6-2113

Fernández, M., and Zúñiga, M. (2006). Amino acid catabolic pathways of lactic acid bacteria. Crit. Rev. Microbiol. 32, 155-183. doi: 10.1080/10408410600880643

Fozo, E. M., Kajfasz, J. K. and Quivey, R. G. Jr. (2004). Low pH-induced membrane fatty acid alterations in oral bacteria. FEMS Microbiol. Lett. 238, 291-295. doi: 10.1111/j.1574-6968.2004.tb09769.x

Gareau, M. G., Wine, E., Rodrigues, D. M., Cho, J. H., Whary, M. T., Philpott, D. J., et al. (2011). Bacterial infection causes stress-induced memory dysfunction in mice. Gut 60, 307-317. doi: 10.1136/gut.2009.202515

Gilliland, S. E., and Speck, M. L. (1977). Deconjugation of bile acids by intestinal lactobacilli. Appl. Environ. Microbiol. 33, 15-18.

Hamon, E., Horvatovich, P., Bisch, M., Bringel, F., Marchioni, E., AoudéWerner, D., et al. (2012). Investigation of biomarkers of bile tolerance in Lactobacillus casei using comparative proteomics. J. Proteome Res. 11, 109-118. doi: $10.1021 / \mathrm{pr} 200828 \mathrm{t}$

Hansen, P., and Lessel, E. F. (1971). Lactobacillus casei (Orla-Jensen) comb. nov. Int. J. Syst. Evol. Microbiol. 21, 69-71. doi: 10.1099/00207713-21-1-69

Hill, C., Guarner, F., Reid, G., Gibson, G. R., Merenstein, D. J., Pot, B., et al. (2014). Expert consensus document: the international scientific association for probiotics and prebiotics consensus statement on the scope and appropriate use of the term probiotic. Nat. Rev. Gastroenterol. Hepatol. 11, 506-514. doi: 10.1038 /nrgastro. 2014.66

Huang, C.-H., Chang, M.-T., and Huang, L. (2014). Use of highly variable gene $(\mathrm{yycH})$ as DNA marker to resolve interspecific relationships within the Lactobacillus casei group and a target for developing novel species-specific Pcr primers. Eur. Food Res. Tech. 239, 719-724. doi: 10.1007/s00217-0142278-9

Huang, C.-H., Chang, M.-T., Huang, L., and Chu, W.-S. (2015). The dnaJ gene as a molecular discriminator to differentiate among species and strain within the Lactobacillus casei group. Mol. Cell. Probes 29, 479-484. doi: 10.1016/j.mcp. 2015.05.016

Huang, C.-H., and Huang, L. (2018). Rapid species- and subspecies-specific level classification and identification of Lactobacillus casei group members using Maldi Biotyper combined with ClinProTools. J. Dairy Sci. 101, 979-991. doi: $10.3168 /$ jds.2017-13642

Huang, C.-H., and Lee, F.-L. (2011). The dnaK gene as a molecular marker for the classification and discrimination of the Lactobacillus casei group. Antonie Van Leeuwenhoek 99, 319-327. doi: 10.1007/s10482-010-9493-6

Huang, L., Shan, Y.-J., He, C.-X., Ren, M.-H., Tian, P.-J., and Song, W. (2016). Effects of L.?paracasei subp. paracasei X12 on cell cycle of colon cancer Ht-29 cells and regulation of mtor signalling pathway. J. Funct. Foods 21, 431-439. doi: 10.1016/j.jff.2015.12.024

Huang, R., Ning, H., Shen, M., Li, J., Zhang, J., and Chen, X. (2017). Probiotics for the treatment of atopic dermatitis in children: a systematic review and metaanalysis of randomized controlled trials. Front. Cell Infect. Microbiol. 7:392. doi: 10.3389/fcimb.2017.00392

Iacumin, L., Ginaldi, F., Manzano, M., Anastasi, V., Reale, A., Zotta, T., et al. (2015). High resolution melting analysis $(\mathrm{Hrm})$ as a new tool for the identification of species belonging to the Lactobacillus casei group and comparison with species-specific PCRS and multiplex PCR. Food Microbiol. 46, 357-367. doi: 10.1016/j.fm.2014.08.007

Ianniello, R. G., Zotta, T., Matera, A., Genovese, F., Parente, E., and Ricciardi, A. (2016). Investigation of factors affecting aerobic and respiratory growth in the oxygen-tolerant strain Lactobacillus casei N87. PLoS One 11:e0164065. doi: 10.1371/journal.pone.0164065

Imlay, J. A. (2003). Pathways of oxidative damage. Annu. Rev. Microbiol. 57, 395-418. doi: 10.1146/annurev.micro.57.030502.090938

Inglin, R. C., Meile, L., and Stevens, M. J. A. (2018). Clustering of panand core-genome of Lactobacillus provides novel evolutionary insights for differentiation. BMC Genomics 19:284. doi: 10.1186/s12864-018-4601-5

Ishikawa, H., Akedo, I., Otani, T., Suzuki, T., Nakamura, T., Takeyama, I., et al. (2005). Randomized trial of dietary fiber and Lactobacillus casei administration for prevention of colorectal tumors. Int. J. Cancer 116, 762-767. doi: 10.1002/ ijc. 21115

Jofré, A., Aymerich, T., and Garriga, M. (2015). Impact of different cryoprotectants on the survival of freeze-dried Lactobacillus rhamnosus and Lactobacillus 
casei/paracasei during long-term storage. Benef. Microbes 6, 381-386. doi: 10. 3920/BM2014.0038

Johansson, M. A., Sjogren, Y. M., Persson, J. O., Nilsson, C., and SverremarkEkstrom, E. (2011). Early colonization with a group of Lactobacilli decreases the risk for allergy at five years of age despite allergic heredity. PLoS One 6:e23031. doi: 10.1371/journal.pone.0023031

Kalliomaki, M., Salminen, S., Arvilommi, H., Kero, P., Koskinen, P., and Isolauri, E. (2001). Probiotics in primary prevention of atopic disease: a randomised placebo-controlled trial. Lancet 357, 1076-1079. doi: 10.1016/S0140-6736(00) 04259-8

Karimi, G., Sabran, M. R., Jamaluddin, R., Parvaneh, K., Mohtarrudin, N., Ahmad, Z., et al. (2015). The anti-obesity effects of Lactobacillus casei strain Shirota versus Orlistat on high fat diet-induced obese rats. Food Nutr. Res. 59:29273. doi: 10.3402/fnr.v59.29273

Kuznetsov, V. D. (1959). A new species of lactic acid bacteria. Mikrobiologiia 28, $248-351$.

Laino, J., Villena, J., Kanmani, P., and Kitazawa, H. (2016). Immunoregulatory effects triggered by lactic acid bacteria exopolysaccharides: new insights into molecular interactions with host cells. Microorganisms 4:E27. doi: 10.3390/ microorganisms4030027

Lee, B., Yin, X., Griffey, S. M., and Marco, M. L. (2015). Attenuation of colitis by Lactobacillus casei $\mathrm{Bl} 23$ Is dependent on the dairy delivery matrix. Appl. Environ. Microbiol. 81, 6425-6435. doi: 10.1128/AEM. 01360-15

Liao, L. K., Wei, X. Y., Gong, X., Li, J. H., Huang, T., and Xiong, T. (2017). Microencapsulation of Lactobacillus casei Lk-1 by spray drying related to its stability and in vitro digestion. Lwt Food Sci. Tech. 82, 82-89. doi: 10.1016/j.lwt. 2017.03.065

Liu, M.-M., Li, S.-T., Shu, Y., and Zhan, H.-Q. (2017). Probiotics for prevention of radiation-induced diarrhea: a meta-analysis of randomized controlled trials. PLoS One 12:e0178870. doi: 10.1371/journal.pone.0178870

Luoto, R., Kalliomäki, M., Laitinen, K. and Isolauri, E. (2010). The impact of perinatal probiotic intervention on the development of overweight and obesity: follow-up study from birth to 10 years. Int. J. Obes. (Lond.) 34, 1531-1537.

Maria, D. A., and Marco, G. (2004). Environmental stress responses in Lactobacillus: a review. Proteomics 4, 106-122. doi: 10.1002/pmic.200300497

Marquis, R. E., Bender, G. R., Murray, D. R., and Wong, A. (1987). Arginine deiminase system and bacterial adaptation to acid environments. Appl. Environ. Microbiol. 53, 198-200.

McGee, R., O'connor, P. M., Russell, D., Dempsey, E. M., Ryan, A. C., Ross, P. R., et al. (2010). Prolonged faecal excretion following a single dose of probiotic in low birth weight infants. Acta Paediatr. 99, 1587-1588. doi: 10.1111/j.16512227.2010.01878.x

Mills, S., Stanton, C., Fitzgerald, G. F., and Ross, R. (2011). Enhancing the stress responses of probiotics for a lifestyle from gut to product and back again. Microbial. Cell Fact. 10(Suppl. 1):S19. doi: 10.1186/1475-2859-10-S1-S19

Monedero, V., Mazé, A., Boël, G., Zúñiga, M., Beaufils, S., Hartke, A., et al. (2006). The phosphotransferase system of Lactobacillus casei: regulation of carbon metabolism and connection to cold shock response. J. Mol. Microbiol. Biotechnol. 12, 20-32. doi: 10.1159/000096456

Moore, E. R. B., and Rosselló-Móra, R. (2011). Maldi-tof Ms: a return to phenotyping in microbial identification? Syst. Appl. Microbiol. 34:1. doi: 10. 1016/j.syapm.2011.01.001

Moser, S. A., and Savage, D. C. (2001). Bile salt hydrolase activity and resistance to toxicity of conjugated bile salts are unrelated properties in Lactobacilli. Appl. Environ. Microbiol. 67, 3476-3480. doi: 10.1128/AEM.67.8.3476-3480. 2001

Muller, J. A., Ross, R. P., Sybesma, W. F., Fitzgerald, G. F., and Stanton, C. (2011). Modification of the technical properties of Lactobacillus johnsonii Ncc 533 by supplementing the growth medium with unsaturated fatty acids. Appl. Environ. Microbiol. 77, 6889-6898. doi: 10.1128/AEM.05213-11

Neville, S. A., Lecordier, A., Ziochos, H., Chater, M. J., Gosbell, I. B., Maley, M. W., et al. (2011). Utility of matrix-assisted laser desorption ionization-time of flight mass spectrometry following introduction for routine laboratory bacterial identification. J. Clin. Microbiol. 49, 2980-2984. doi: 10.1128/JCM.00431-11

Nezhad, M. H., Knight, M., and Britz, M. L. (2012). Evidence of changes in cell surface proteins during growth of Lactobacillus casei under acidic conditions. Food Sci. Biotechnol. 21, 253-260. doi: 10.1007/s10068-012-0033-1
Nunez, I. N., Galdeano, C. M., De Leblanc Ade, M., and Perdigon, G. (2014). Evaluation of immune response, microbiota, and blood markers after probiotic bacteria administration in obese mice induced by a high-fat diet. Nutrition 30 , 1423-1432. doi: 10.1016/j.nut.2014.03.025

Osterlund, P., Ruotsalainen, T., Korpela, R., Saxelin, M., Ollus, A., Valta, P., et al. (2007). Lactobacillus supplementation for diarrhoea related to chemotherapy of colorectal cancer: a randomised study. Br. J. Cancer 97, 1028-1034. doi: $10.1038 /$ sj.bjc. 6603990

Owusu-Kwarteng, J., Tano-Debrah, K., Akabanda, F., and Jespersen, L. (2015). Technological properties and probiotic potential of Lactobacillus fermentum strains isolated from West African fermented millet dough. BMC Microbiol. 15:261. doi: 10.1186/s12866-015-0602-6

Ozen, M., and Dinleyici, E. C. (2015). The history of probiotics: the untold story. Benef. Microbes 6, 159-165. doi: 10.3920/BM2014.0103

Pace, F., Pace, M., and Quartarone, G. (2015). Probiotics in digestive diseases: focus on Lactobacillus Gg. Minerva Gastroenterol. Dietol. 61, 273-292.

Palomino, M. M., Allievi, M. C., Gründling, A., Sanchez-Rivas, C., and Ruzal, S. M. (2013). Osmotic stress adaptation in Lactobacillus casei $\mathrm{Bl} 23$ leads to structural changes in the cell wall polymer lipoteichoic acid. Microbiology 159, 2416-2426. doi: 10.1099/mic.0.070607-0

Papadimitriou, K., Alegria, A., Bron, P. A., De Angelis, M., Gobbetti, M., Kleerebezem, M., et al. (2016). Stress physiology of lactic acid bacteria. Microbiol. Mol. Biol. Rev. 80, 837-890. doi: 10.1128/MMBR. 00076-15

Parolin, C., Marangoni, A., Laghi, L., Foschi, C., Ñahui Palomino, R. A., Calonghi, N., et al. (2015). Isolation of vaginal lactobacilli and characterization of anti-candida activity. PLoS One 10:e0131220. doi: 10.1371/journal.pone. 0131220

Pavlovic, M., Huber, I., Konrad, R., and Busch, U. (2013). Application of maldi-tof Ms for the identification of food borne bacteria. Open Microbiol. J. 7, 135-141. doi: 10.2174/1874285801307010135

Petti, C. A., Polage, C. R., and Schreckenberger, P. (2005). The role of 16 S rRNA gene sequencing in identification of microorganisms misidentified by conventional methods. J. Clin. Microbiol. 43, 6123-6125. doi: 10.1128/JCM.43. 12.6123-6125.2005

Piuri, M., Sanchez-Rivas, C., and Ruzal, S. M. (2005). Cell wall modifications during osmotic stress in Lactobacillus casei. J. Appl. Microbiol. 98, 84-95. doi: 10.1111/j.1365-2672.2004.02428.x

Rafter, J., Bennett, M., Caderni, G., Clune, Y., Hughes, R., Karlsson, P. C., et al. (2007). Dietary synbiotics reduce cancer risk factors in polypectomized and colon cancer patients. Am. J. Clin. Nutr. 85, 488-496. doi: 10.1093/ajcn/85.2.488

Reale, A., Di Renzo, T., Rossi, F., Zotta, T., Iacumin, L., Preziuso, M., et al. (2015). Tolerance of Lactobacillus casei, Lactobacillus paracasei and Lactobacillus rhamnosus strains to stress factors encountered in food processing and in the gastro-intestinal tract. LWT Food Sci. Technol. 60, 721-728. doi: 10.1016/j.lwt. 2014.10.022

Reunanen, J., Von Ossowski, I., Hendrickx, A. P., Palva, A., and De Vos, W. M. (2012). Characterization of the Spacba pilus fibers in the probiotic Lactobacillus rhamnosus Gg. Appl. Environ. Microbiol. 78, 2337-2344. doi: 10.1128/AEM. 07047-11

Ryan, P. M., Ross, R. P., Fitzgerald, G. F., Caplice, N. M., and Stanton, C. (2015). Sugar-coated: exopolysaccharide producing lactic acid bacteria for food and human health applications. Food Funct. 6, 679-693. doi: 10.1039/C4FO00529E

Samb-Ba, B., Mazenot, C., Gassama-Sow, A., Dubourg, G., Richet, H., Hugon, P., et al. (2014). Maldi-tof identification of the human gut microbiome in people with and without diarrhea in senegal. PLoS One 9:e87419. doi: 10.1371/journal. pone.0087419

Sanchez, M., Darimont, C., Drapeau, V., Emady-Azar, S., Lepage, M., Rezzonico, E., et al. (2014). Effect of Lactobacillus rhamnosus CGMCC1.3724 supplementation on weight loss and maintenance in obese men and women. $\mathrm{Br}$. J. Nutr. 111, 1507-1519. doi: 10.1017/S0007114513003875

Sanders, M. E., Shane, A. L., and Merenstein, D. J. (2016). Advancing probiotic research in humans in the United States: challenges and strategies. Gut Microbes 7, 97-100. doi: 10.1080/19490976.2016.1138198

Savino, M. J., Sanchez, L. A., Saguir, F. M., and De Nadra, M. C. (2012). Lactic acid bacteria isolated from apples are able to catabolise arginine. World J. Microbiol. Biotechnol. 28, 1003-1012. doi: 10.1007/s11274-011-0898-9 
Schröder, H., Langer, T., Hartl, F. U., Bukau, B. (1993). DNAK, DNAJ and GrpE form a cellular chaperone machinery capable of repairing heat-induced protein damage. EMBO J. 12, 4137-4144.

Segers, M. E., and Lebeer, S. (2014). Towards a better understanding of Lactobacillus rhamnosus Gg-host interactions. Microb Cell Fact 13(Suppl. 1):S7. doi: 10.1186/1475-2859-13-S1-S7

Smokvina, T., Wels, M., Polka, J., Chervaux, C., Brisse, S., Boekhorst, J., et al. (2013). Lactobacillus paracasei comparative genomics: towards species pangenome definition and exploitation of diversity. PLoS One 8:e68731. doi: 10. 1371/journal.pone.0068731

So, S. S., Wan, M. L., and El-Nezami, H. (2017). Probiotics-mediated suppression of cancer. Curr. Opin. Oncol. 29, 62-72. doi: 10.1097/CCO.0000000000000342

Soukoulis, C., Singh, P., Macnaughtan, W., Parmenter, C., and Fisk, I. D. (2016). Compositional and physicochemical factors governing the viability of Lactobacillus rhamnosus Gg embedded in starch-protein based edible films. Food Hydrocoll. 52, 876-887. doi: 10.1016/j.foodhyd.2015.08.025

Stackebrandt, E., Frederiksen, W., Garrity, G. M., Grimont, P. A., Kampfer, P., Maiden, M. C., et al. (2002). Report of the ad hoc committee for the reevaluation of the species definition in bacteriology. Int. J. Syst. Evol. Microbiol. 52, 1043-1047.

Stefanovic, E., and McAuliffe, O. (2018). Comparative genomic and metabolic analysis of three Lactobacillus paracasei cheese isolates reveals considerable genomic differences in strains from the same niche. BMC Genomics 19:205. doi: 10.1186/s12864-018-4586-0

Sun, Z., Harris, H. M., Mccann, A., Guo, C., Argimon, S., Zhang, W., et al. (2015). Expanding the biotechnology potential of lactobacilli through comparative genomics of 213 strains and associated genera. 6:8322. doi: 10 . 1038/ncomms 9322

Thakur, B. K., Saha, P., Banik, G., Saha, D. R., Grover, S., Batish, V. K., et al. (2016). Live and heat-killed probiotic Lactobacillus casei Lbs2 protects from experimental colitis through toll-like receptor 2-dependent induction of T-regulatory response. Int. Immunopharmacol. 36, 39-50. doi: 10.1016/j.intimp. 2016.03.033

Tindall, B. (2008). The type strain of Lactobacillus casei is Atcc 393, Atcc 334 cannot serve as the type because it represents a different taxon, the name Lactobacillus paracase $i$ and its subspecies names are not rejected and the revival of the name 'Lactobacillus zeae'contravenes rules 51b (1) and (2) of the international code of nomenclature of bacteria. opinion 82. Int. J. Syst. Evol. Microbiol. 58, 1764-1765. doi: 10.1099/ijs.0.2008/005330-0

Tiptiri-Kourpeti, A., Spyridopoulou, K., Santarmaki, V., Aindelis, G., Tompoulidou, E., Lamprianidou, E. E., et al. (2016). Lactobacillus casei exerts anti-proliferative effects accompanied by apoptotic cell death and up-regulation of trail in colon carcinoma cells. PLoS One 11:e0147960. doi: 10.1371/?journal.pone.0147960

Toh, H., Oshima, K., Nakano, A., Takahata, M., Murakami, M., Takaki, T., et al. (2013). Genomic adaptation of the Lactobacillus casei group. PLoS One 8:e75073. doi: 10.1371/journal.pone.0075073.g004

Tynkkynen, S., Satokari, R., Saarela, M., Mattila-Sandholm, T., and Saxelin, M. (1999). Comparison of ribotyping, randomly amplified polymorphic DNA analysis, and pulsed-field gel electrophoresis in typing of Lactobacillus rhamnosus and L. casei strains. Appl. Environ. Microbiol. 65, 3908-3914.

Tytgat, H. L., Douillard, F. P., Reunanen, J., Rasinkangas, P., Hendrickx, A. P., Laine, P. K., et al. (2016). Lactobacillus rhamnosus Gg outcompetes Enterococcus faecium via mucus-binding pili: evidence for a novel and heterospecific probiotic mechanism. Appl. Environ. Microbiol. 82, 5756-5762. doi: 10.1128/ AEM.01243-16

van de Guchte, M., Serror, P., Chervaux, C., Smokvina, T., Ehrlich, S. D., and Maguin, E. (2002). Stress responses in lactic acid bacteria. Antonie Van Leeuwenhoek 82, 187-216. doi: 10.1023/A:1020631532202

Vásquez, A., Molin, G., Pettersson, B., Antonsson, M., and Ahrné, S. (2005). DNA-based classification and sequence heterogeneities in the 16S rRNA genes of Lactobacillus casei/paracasei and related species. Syst. Appl. Microbiol. 28, 430-441. doi: 10.1016/j.syapm.2005.02.011

Wang, G., Yin, S., An, H., Chen, S., and Hao, Y. (2011). Coexpression of bile salt hydrolase gene and catalase gene remarkably improves oxidative stress and bile salt resistance in Lactobacillus casei. J. Ind. Microbiol. Biotechnol. 38, 985-990. doi: 10.1007/s10295-010-0871-x

Weisburg, W. G., Barns, S. M., Pelletier, D. A., and Lane, D. J. (1991). 16S ribosomal DNA amplification for phylogenetic study. J. Bacteriol. 173, 697-703. doi: 10.1128/jb.173.2.697-703.1991

WHO (2015). WHO Cancer Control Programme [Online]. Available at: http://www.who.int/cancer/en/

$\mathrm{Wu}, \mathrm{C} ., \mathrm{He}, \mathrm{G}$., and Zhang, J. (2014). Physiological and proteomic analysis of Lactobacillus casei in response to acid adaptation. J. Ind. Microbiol. Biotechnol. 41, 1533-1540. doi: 10.1007/s10295-014-1487-3

Wu, C., Zhang, J., Chen, W., Wang, M., Du, G., and Chen, J. (2012a). A combined physiological and proteomic approach to reveal lactic-acid-induced alterations in Lactobacillus casei Zhang and its mutant with enhanced lactic acid tolerance. Appl. Microbiol. Biotechnol. 93, 707-722. doi: 10.1007/s00253-0113757-6

Wu, C., Zhang, J., Du, G., and Chen, J. (2013). Aspartate protects Lactobacillus casei against acid stress. Appl. Microbiol. Biotechnol. 97, 4083-4093. doi: 10. 1007/s00253-012-4647-2

Wu, R., Zhang, W., Sun, T., Wu, J., Yue, X., Meng, H., et al. (2011). Proteomic analysis of responses of a new probiotic bacterium Lactobacillus casei zhang to low acid stress. Int. J. Food Microbiol. 147, 181-187. doi: 10.1016/j.ijfoodmicro. 2011.04 .003

Wu, C., Zhang, J., Wang, M., Du, G., and Chen, J. (2012b). Lactobacillus casei combats acid stress by maintaining cell membrane functionality. J. Ind. Microbiol. Biotechnol. 39, 1031-1039. doi: 10.1007/s10295-012-1104-2

Wuyts, S., Wittouck, S., De Boeck, I., Allonsius, C. N., Pasolli, E., and Segata, N. (2017). Large-scale phylogenomics of the Lactobacillus casei Group highlights taxonomic inconsistencies and reveals novel clade-associated features. 2:e00061-17.

Xu, M., Gagné-Bourque, F., Dumont, M. J., and Jabaji, S. (2016). Encapsulation of Lactobacillus casei Atcc 393 cells and evaluation of their survival after freezedrying, storage and under gastrointestinal conditions. J. Food Eng. 168, 52-59. doi: 10.1016/j.jfoodeng.2015.07.021

Zhang, G. Q., Hu, H. J., Liu, C. Y., Zhang, Q., Shakya, S., and Li, Z. Y. (2016). Probiotics for prevention of atopy and food hypersensitivity in early childhood: a prisma-compliant systematic review and meta-analysis of randomized controlled trials. Medicine 95:e2562. doi: 10.1097/MD.0000000000002562

Zhang, W. Y., Wu, R. N., Sun, Z. H., Sun, T. S., Meng, H., and Zhang, H. P. (2009). Molecular cloning and characterization of bile salt hydrolase in Lactobacillus casei Zhang. Ann. Microbiol. 59, 721-726. doi: 10.1007/BF03179214

Zhang, Y. M., and Rock, C. O. (2008). Membrane lipid homeostasis in bacteria. Nat. Rev. Microbiol. 6, 222-233. doi: 10.1038/nrmicro1839

Zotta, T., Ricciardi, A., Ianniello, R. G., Parente, E., Reale, A., Rossi, F., et al. (2014). Assessment of aerobic and respiratory growth in the Lactobacillus casei group. PLoS One 9:e99189. doi: 10.1371/journal.pone.0099189

Conflict of Interest Statement: The authors declare that the research was conducted in the absence of any commercial or financial relationships that could be construed as a potential conflict of interest.

Copyright (c) 2018 Hill, Sugrue, Tobin, Hill, Stanton and Ross. This is an open-access article distributed under the terms of the Creative Commons Attribution License (CC BY). The use, distribution or reproduction in other forums is permitted, provided the original author(s) and the copyright owner(s) are credited and that the original publication in this journal is cited, in accordance with accepted academic practice. No use, distribution or reproduction is permitted which does not comply with these terms. 